\title{
Revitalizing the Role of the Regional Government Internal Supervision Apparatus (APIP) to Realize Clean Governance in Indonesia
}

\author{
Mashun Mukromin Ahmad ${ }^{1}$, Hardi Warsono ${ }^{2}$ \\ \{mashun34@students.undip.ac.id ${ }^{1}$,warsono_hardi@live.undip.ac.id ${ }^{2}$ \} \\ Universitas Diponegoro, Indonesia ${ }^{1,2}$
}

\begin{abstract}
Revitalization of regional APIP (Aparat Pengawas Internal Pemerintah) needs to be carried out because its position and role are considered to be less effective in supervision their own superiors. The purpose of this study is to find out how the role of the Regional Inspectorate in the Regency/City Government and to determine the inhibiting factors of the Regional Inspectorate in carrying out its role. This research uses descriptive method by searching literature review. This type of data uses secondary data. The results showed that the position of the Regional Inspectorate under the regional head (Bupati) was considered ineffective in carrying out its functions and roles, and its independence was not optimal. APIP's bureaucratic governance needs to be improved, and the development of human resource competencies (auditors) needs to be done continuously to realize clean governance.
\end{abstract}

Keywords: Revitalization, Supervision, Regional APIP.

\section{Introduction}

Since the reform era, the condition of the bureaucracy in Indonesia has indeed not been said to be in an ideal position. Corruption, collusion and nepotism (KKN) practices also cannot be denied often in government agencies. The commitment and consistency of the government to create a clean, accountable and professional bureaucracy continues to be questioned [1]. Cases of Operation Catching Hands (OTT) by the Corruption Eradication Commission (KPK) in the regional government bureaucracy continue to occur.

Bureaucracy must be entirely devoted to the interests of the people and work to provide excellent, transparent, accountable services and be free from corruption, collusion and nepotism. This is the spirit that underlies the implementation of government bureaucratic reform in Indonesia. Bureaucratic reform is meaningful as a structured, systematic change towards improving bureaucratic performance [2]. Bureaucratic reform is also marked by a series of efforts to reorganize the bureaucratic process from the highest level to the lowest and make new breakthroughs with steps that are gradual, concrete, realistic, truly, thoughtfully outside existing habits/routines, paradigm changes, and with external efforts ordinary [3].

To realize good governance and clean governance, the government also moves to formulate a regulation so that it becomes the basis for implementing bureaucratic reform by issuing Presidential Regulation No. 80 of 2011 concerning the Grand Design of the Indonesian Bureaucratic Reform 2010 - 2025. Until now the implementation of the national bureaucratic reform has entered the second phase marked by the preparation of the 2015-2019 Bureaucratic 
Reform Road Map through the Minister of Administrative Reforms and Bureaucratic Reform of the Republic of Indonesia No. 11 of 2015. In the Road Map three (3) targets and 8 (eight) areas of change in the 2015 - 2019 bureaucratic reform was determined.

The three targets of Bureaucratic Reform are: 1) Clean and accountable bureaucracy; 2) Effective and efficient bureaucracy; and 3) Bureaucracy that has quality public services. To realize clean governance, of the 8 areas of change, the area of supervision is one of the most important things [4].

Various irregularities that occur in the bureaucracy, one of the causes is the weakness of the surveillance system. The weakness of the surveillance system encourages the growth of corrupt or other negative behaviors that are becoming more and more, so that it turns into a habit. Therefore changes in corrupt behavior of the apparatus must also be directed through changes or strengthening of the surveillance system [5].

At the local government level, internal supervision is carried out by the regional Inspectorate as the Government Internal Supervision Apparatus (APIP). According to the Regulation of the Minister of Administrative Reform and Bureaucratic Reform of the Republic of Indonesia No. PER/05/M.PAN/03/2008 concerning Auditing Standards for Government Internal Supervisory Apparatus, Government Internal Supervision Apparatus (APIP) is a Government Agency that has the main task and function of conducting supervision, and consists of:

a) The Financial and Development Supervisory Agency (BPKP) responsible to the President;

b) Inspectorate General (Itjen)/Main Inspectorate (Ittama)/Inspectorate responsible to the Minister/Head of Non-Departmental Government Institutions (LPND);

c) Provincial Government Inspectorate responsible to the Governor, and;

d) Regency/City Government Inspectorate responsible to the Regent / Mayor.

The role of supervisors in bureaucratic management is carried out by the Inspectorate who is also referred to as the Government Internal Supervision Apparatus (APIP). The Inspectorate carries out its duties as a supervisor of the implementation of the program carried out by regional apparatus organizations (OPD). The effective role of the Regional APIP refers to Government Regulation Number 60 of 2008 concerning Government Internal Control System article 11, namely:

a) Providing adequate confidence in obedience, efficiency, efficiency and effectiveness in achieving the objectives of carrying out the tasks and functions of government agencies;

b) Providing early warning and increasing the effectiveness of risk management in carrying out the tasks and functions of government agencies; and

c) Maintain and improve the quality of governance in carrying out the duties and functions of government agencies.

The effective role of the Government Internal Supervision Apparatus (APIP) is expected to ensure that the implementation of regional government affairs is carried out in an orderly, efficient and effective manner in accordance with the plans and regulations of the legislation and can also encourage the realization of good governance, clean and authoritative, free from irregularities and abuse of power and practices of corruption, collusion and nepotism (KKN) so that the concepts of good governance and clean government synergize with the realization of the ideals of regional autonomy, namely to accelerate the realization of public welfare [6].

Based on the publication of Indonesia Corruption Watch (ICW), the ineffective role of the supervisory apparatus in the regions is one of the causes of the increasing prevalence of corruption cases and poor regional governance. Corruption is still prevalent in the regions, 
autonomy becomes auto money, the supervision system is not optimal enough to encourage massive public officials to engage in corrupt practices [7].

Around July 2016, the Mejayan District Attorney once named an APIP as a corruption case suspect. The APIP referred to was the District Inspector of Madiun Benny Adiwijaya. Beny is suspected of misusing the budget of the Inspectorate of Madiun Regency which was previously named the Supervisory Agency in the 2012-2014 fiscal year. Then earlier in May 2016, the Attorney General's Office detained Bengkalis Burhanuddin District Secretary and Bengkalis Regency Inspector Mukhlis. Both together with the Bengkalis Regent in the 20102015 period, Herliyan Saleh was suspected of corruption in the government's capital participation in PT Bumi Laksana Jaya (BLJ) [8].

From the author's summary, based on research that has been done related to APIP, shows that the performance of Regional APIP is not optimal. the results of research from Hidayat (2018) The Government Internal Supervisory Apparatus (APIP) must continue to make changes and maximize the main tasks and functions in order to realize good governance and clean governance. Because so far the function and role of regional APIP has not been optimal with various obstacles in the implementation of supervision [9]. Yohanes [5] argues that the limited resources of the apparatus; weak independence; and the unavailability of supporting facilities to carry out quality inspection of physical facilities and infrastructure is an obstacle to the role of the regional APIP.

Likewise, according to the KPK Spokesperson, Febri Diansyah, the strengthening of the APIP as part of efforts to prevent corruption that is increasingly widespread ensnare a number of regional heads. Based on the results of a study by the Deputy for the Prevention of the Corruption Eradication Commission, corruption acts have ensnared regional heads due to the weakness of APIP. For this reason, APIP needs to be revitalized in terms of its structure and independence.

\subsection{Research Purposes}

The purpose of this study is to find out how the role of the Regional Inspectorate in the Regency/City Government and to determine the inhibiting factors of the Regional Inspectorate in carrying out its role.

\subsection{Research Gap}

Writing about the role thus the Regional APIP has been done a lot. Every writing has its own point of view. General research that has been conducted using the case study method by looking at cases in one district/city or province. In this article the author uses the method of literature review, which is about research published on participation with Regional APIP, then presents it as a general description of regional APIP in Indonesia. Understand the systems and rules that apply to Regional APIPs throughout Indonesia.

\section{Research Method}

The method used to compile this article uses the literature review. The type of data used is secondary data. The technique for inviting data is done by examining books, journals, 
statutory regulations, research reports, and internet sites. Literature review method used to answer research problems by looking at the general APIP Regional portrait in Indonesia.

\section{Result and Discussion}

The role and performance of APIP has received a lack of attention from various parties, corruption at the local government level continues to occur. APIP as a supervisor has also been deemed unable to work optimally in preventing corruption. Then the spotlight again is about the position of APIP under the head of the region, this makes the independence of the regional APIP considered not optimal.

Regional APIP can carry out its functions well if it has support from both internal and external. Limited apparatus resources; weak independence; and the unavailability of supporting facilities to carry out quality inspection of physical facilities and infrastructure into several examples of regional APIP inhibiting factors that can perform their roles and functions optimally.

\subsection{Regional APIP Performance}

In accordance with the provisions of Law No. 23 of 2014 concerning Regional Government, the last time amended by Law No. 9 of 2015, regional heads are required to carry out guidance and supervision of regional authorities. In conducting such guidance and supervision, the regional head is assisted by a Provincial Inspectorate or Regency/City Inspectorate. So, what if APIP does not help regional heads supervise, but is involved in the chain of corruption? Moreover, corruption is carried out jointly by the regional head or other regional apparatus that should be monitored?

Chairman of the Corruption Eradication Commission (KPK), Agus Rahardjo said that the Government Internal Supervision Apparatus (APIP) has not been able to function in preventing corruption in the government environment so far. The reason is, no report received by the KPK regarding corruption in the region came from APIP. The KPK has felt that APIP has not been functioning optimally for a long time. Specifically, in the regions we highlight cases handled by the KPK, none of the reports came from APIP.

Regarding APIP's involvement in the bribery case, KPK Deputy Chairman Laode M Syarif deeply regretted it. He said the Inspectorate was an internal oversight of the regional government. However, why do people who are supposed to serve as internal supervisors actually become links in the bribery process. Then related to a number of corruption cases that ensnared APIP, Professor of Government Science Padjadjaran University Prof. Nandang Alamsah Deliarnoor argued, these cases were positive phenomena. The legal process against the APIPs proved that the check and balances system was running. Prof. Nandang also revealed, according to Peter Carey, British practice was free from corruption after passing through four movements simultaneously. First, encouraging public-private partnerships. Second, forming a special parliamentary commission to examine the country's financial statements. Third, increasing the salaries of civil servants including judges, and fourth, mental revolution.

The function of the Inspectorate seems not to have been maximized, the regional head still sees it as a complement in bureaucratic management. The findings of the examination were not directed at strategic matters. This lack of attention causes the lack of motivation of 
ASN in the Inspectorate and has an impact on diminishing performance. In fact, it can also be involved in justifying or protecting corrupt practices.

The fact of the weak role of the regional APIP can also be seen from the data presented by the Indonesian Ombudsman. At least in 2015 and 2016 the local government was ranked as the most widely reported government agency to the Indonesian Ombudsman. If in 2015 there were 2,914 reports, this number increased to 3,638 reports in 2016 or $40 \%$ of the total reports. This high number reflects a lot of things related to governance in the regions, including their internal oversight function. Not only that, many problems in the regional government were taken to the top level up to the President as a result of weak internal supervision, including in the provincial, district or city government.

Harahap (2018) argues that revitalizing State Civil Service Management or ASN Management through dismissal dishonorable to civil servants involved in corruption needs to be done because all this time the dishonorable dismissal that is part of ASN Management has not been implemented maximally evidenced by the many cases of civil servants who have not been dishonorably dismissed in committing criminal cases of corruption [10].

In addition, a good recruitment process can also be an alternative to improve the role of the regional APIP in the future. The study by Udeh (2016) found, among other things, that in terms of availability of adequate punishments, they were not effectively applied across boards for violations of internal audit procedures. It concluded that efforts should be geared towards updating the knowledge of internal auditors rather than engaging in interminable search for error-proof internal audit procedures. And then recommended a thorough and transparent recruitment process for internal audits [11].

Basically, in this reform era the functions and roles of the Regional APIP have been supported by strong regulations. However, the implementation requires commitment from the apparatus and independence from various interested parties. This is a challenge for the Regional APIP to create a clean bureaucracy and can prevent corruption cases in the regions.

\subsection{Inhibiting Factors in the Role of Regional APIP}

Changes in the system in Indonesia after the reform, from centralization to decentralization, have had an impact on the increasingly large handover of authority and the increasingly less intervention of the Central Government to Regional Governments. This means that supervision of regional government operations must be increased.

In the era of regional autonomy, local governments have a broad function in the effort to shape the Indonesian government on the basis of implementing good governance. Indonesia in general depends on how the local government behaves. Autonomous regions have broad authority to manage their own households. That is why the role of inspectors in the regions is important.

Research conducted by Cohen and Sayag [12], the results of this study concluded that organizational independence influences internal audit quality. The position of internal auditors in the internal governance structure can influence the level of independence and authority of internal auditors [13].

There are several obstacles and problems that are owned by the Regional Inspectorate in carrying out supervision and coaching of local government agencies, namely internal and external barriers. Institutional internal barriers namely lack of apparatus human resource support and lack of financial resource support in carrying out institutional operationalization. Meanwhile, the challenges externally are influenced by the legal position and authority of the Regional Inspectorate that is inseparable from the practical political frame and high political 
intervention on the existence of the apparatus in the Regional Inspectorate.The high level of political control in the work of the Regional Inspectorate gave birth to the results of auditing and the supervision and guidance produced by the Inspectorate could not be maximized [14].

According to Deputy Chairman of the Corruption Eradication Commission (KPK) Alexander Marwata, APIP has not been maximally empowered because the number of auditors is not in balance with its duties. Even though APIP plays a big role in suppressing corruption crimes in government, "Not to mention the intervention of regional heads at the same level who want to do their job, for that we have proposed strengthening APIP so that inspectors do not need regional head approval".

According to Mintayu [15] to realize optimal audit quality is the need to provide training to increase audit independence and experience [16].

The Financial and Development Supervisory Agency (BPKP) seeks to improve the capabilities of APIP through assessment and assistance. To improve the capabilities of APIP, there are 5 levels in it, each level shows the condition and quality of APIP. Level 1: Initial (APIP has not been able to guarantee the governance process according to regulations and has not been able to prevent corruption). Level 2: Infrastructure (APIP is able to guarantee governance processes in accordance with regulations and able to detect corruption). Level 3: Integrated (APIP is able to assess the efficiency, effectiveness, economics of an activity and able to provide consultation on governance, risk management and internal control). Level 4: Managed (APIP is able to provide overall assurance on governance, risk management and internal control). Level 5: Optimizing (APIP becomes an agent of change).

In 2019 it is targeted that $85 \%$ of the total APIP 628 reaches level 3. The meaning of level 3 is that APIP can assess the efficiency, effectiveness, economics of an activity, and provide consultation on governance, risk management and internal control. This increased capability has changed APIP's behavior. If there used to be a person who compromised on findings with the aim of getting reciprocity in the form of material, then the practice can now be eroded.

The findings are not only about administrative matters, but can go deeper to detect fraud and recover state losses. APIP is demanded to have the courage to submit input to regional heads regarding clean governance. The role of APIP is also broadened by the existence of a cooperation agreement between APIP and law enforcement officials (APH) related to the handling of reports or public complaints in the administration of regional government. The Inspectorate is also actively involved in the coordination, supervision and prevention carried out by the Corruption Eradication Commission (KPK). As a partner, the inspectorate always cooperates with the KPK in terms of prevention through the Report of the State's Assets (LHKPN) and anti-corruption education [6].

The role of APIP in the regions in providing an early warning system is considered to be lacking. The position and role of APIP which is equal to the heads of other agencies even under the Regional Secretary (Sekda) makes APIP's role only as a mere complement. At present APIP is only responsible to the Regional Head, this certainly makes APIP's independence not optimal.

There are three options to strengthen the role of APIP in the regions. The first option, APIP in the regions will report directly to the central APIP, so that any potential deviations can be immediately detected and immediately reported to the center.The second option, APIP submits the report not only to the Regional Head, but also to the central APIP. As for the third option, the choice that was also proposed by the Ministry of Home Affairs and the KPK was that APIP in the Province was appointed by the Minister of Home Affairs while in the district / city by the Governor [17]. 


\section{Conclusion}

The results of the study showed that APIP's position was equivalent to that of other department heads even under the Regional Secretary (Sekda) and under the regional head considered ineffective in carrying out its functions and roles, and its independence became not optimal. In fact, until now, the KPK has never received a report related to allegations of corruption from APIP. In fact, as a supervisor, APIP should know the indications first. Therefore, revitalization needs to be done so that APIP as an internal supervisor is able to detect corruption within the local government.

To improve the capabilities of APIP, support and commitment is needed from all shareholders, as well as the leadership of APIP itself. The following three options are believed to be able to strengthen the role of APIP. First, regional APIPs will report directly to the central APIP. Second, APIP submits the report not only to the Regional Head, but also to the central APIP. Third, the choice which is also a proposal of the Ministry of Home Affairs together with the KPK is that APIP in the Province was appointed by the Minister of Home Affairs while in the district / city by the Governor.

The obstacles of APIP in carrying out its functions and roles can be overcome by improving APIP's bureaucratic governance and developing human resource competencies (auditors). It starts with a good recruitment process; sound budgetary support and independence are strengthened. With good supervision, a government that is clean from corruption, collusion and nepotism $(\mathrm{KKN})$ will be realized towards clean governance.

\section{References}

[1] A. H. Saputra, "Reformasi Birokrasi: Pondasi Wujudkan Good and Clean Government," 2016. .

[2] A. Primanto, S. Suwitri, and H. Warsono, "Bureaucratic Reform: A Way to Eliminate Corruption, Collusion, and Nepotism Practices in Indonesia," Int. J. Econ. Commer. Manag., vol. 2, no. 10, 2014.

[3] H. Warsono, "Reformasi birokrasi di Indonesia; isu dan tantangan." Asosiasi Ilmuwan Administrasi Negara, 2016.

[4] DPR RI, "Dokumen Road Map Reformasi Birokrasi 2015-2019," www.dpr.go.id, 2015.

[5] E. Yohanes, "Peran Aparat Pengawas Intern Pemerintah (APIP) dalam Penyelenggaraan Pemerintahan Daerah di Kabupaten Bulungan," J. Paradig., vol. 7, no. 2, pp. 55-64, 2018.

[6] M. Isa Thoriq A, "Upaya revitalisasi Inspektorat daerah," 2018.

[7] Kompas.com, "ICW: Mayoritas Pelaku Korupsi dari Pejabat Daerah Merata di Seluruh Indonesia," 2014. .

[8] N. Rahmi, "APIP Sang Pengawas, Bukan Bagian Mata Rantai Korupsi,” 2017. .

[9] T. Hidayat, "Peran Inspektorat Daerah sebagai Aparat Pengawas Internal Pemerintah di Provinsi Lampung," 2018.

[10] N. A. Harahap, "Revitalisasi Manajemen Aparatur Sipil Negara Melalui Pemberhentian Tidak Dengan Hormat Bagi Pegawai Negeri Sipil Yang Terlibat Tindak Pidana Korupsi," J. Panor. Huk., vol. 3, no. 2, pp. 155-170, 2018.

[11] S. N. Udeh and E. O. Nwadialor, "Evaluation of effectiveness of internal audit in the Nigerian public sector," Eur. J. Business, Econ. Account., vol. 4, no. 3, 2016.

[12] A. Cohen and G. Sayag, "The effectiveness of internal auditing: an empirical examination of its determinants in Israeli organisations," Aust. Account. Rev., vol. 20, no. 3, pp. 296-307, 2010.

[13] K. C. A. Hamid, "A Review on Independence and Authority of Internal Auditor," Adv. Sci. Lett., vol. 21, no. 6, pp. 1621-1623, 2015.

[14] S. N. Rahayu, "Revitalisasi Pengawasan Intern Pemerintahan Daerah Melalui Inspektorat," 
2017. .

[15] C. S. Mintayu, "Pengaruh Independensi dan Pengalaman Audit terhadap Kualitas Audit Aparat Inspektorat dalam Pengawasan Keuangan Daerah (Studi Kasus di Inspektorat Kabupaten Tulungagung)," REVITALISASI, vol. 5, no. 3, pp. 13-23, 2019.

[16] T. J. Permata, "Tekan Angka Korupsi, KPK Dorong Penguatan Aparat Pengawasan Intern Pemerintah," 2019.

[17] menpan.go.id, "Tiga Opsi Perkuat Peran APIP Daerah,” 2017. . 